\title{
O CONTEXTO SOCIAL E AÇÕES PEDAGÓGICAS NAS ES- COLAS INDÍGENAS AKWẼ
}

\author{
XERENTE ${ }^{1}$, Rogério Srône \\ XERENTE², Sílvia Letícia Gomes da Silva \\ Pesquisadores da Ação 'Saberes Indígenas na Escola'
}

\section{RESUMO}

Esse artigo apresenta os resultados de um trabalho de pesquisa realizado no Centro de Ensino Médio Indígena Xerente - Warã (CEMIX-WARÃ) e na Escola Estadual Indígena Sakruiwẽ. A primeira está localizada na Terra Indígena Xerente e a segunda na Terra Indígena Funil. No desenvolvimento da pesquisa analisamos as características dessas duas escolas e o contexto em que elas se encontram, bem como as atividades desenvolvidas pelos professores indígenas Akwẽ que lecionam nessas unidades de ensino, com o objetivo de perceber os efeitos da atuação dessas escolas e das ações pedagógicas de professores Akwẽ na formação de alunos indígenas. E, para tanto, seguimos alguns passos metodológicos que incluíram estudo bibliográfico pertinente ao objeto de pesquisa e à educação escolar indígena, contato com sujeitos do processo de educação escolar e não escolar na comunidade e com ações pedagógicas nas unidades de ensino acima citadas. Esse processo nos fez compreender que a educação escolar indígena necessita encontrar seu caminho através de ações pedagógicas em sintonia com o contexto social indígena, para de fato ser a escola indígena que a comunidade deseja.

Palavras-chave: Escola indígena. Professor indígena. Ações pedagógicas. Cultura Akwẽ.

1 Licenciado em Educação Intercultural com habilitação em Ciências da Cultura pela Universidade Federal de Goiás (UFG). Pós-Graduado Lato Sensu em Culturas e Histórias dos Povos Indígenas pela Universidade Federal do Tocantins (UFT). Professor de Educação Básica na Escola Estadual Indígena Waĩpainẽrê. Membro Titular do Conselho Estadual de Educação Escolar Indígena do Tocantins. E-mail: rogeriosronex@hotmail.com.

2 Licenciada em Pedagogia pela Universidade Federal do Tocantins (UFT) e em Educação Intercultural com Habilitação em Ciências da Linguagem pela Universidade Federal de Goiás (UFG). Professora de Educação Básica na Escola Estadual Indígena Sakruiwẽ. E-mail: silviaketi_gsx@hotmail.com. 


\section{ABSTRACT}

This paper presents the results of a research project carried out at the Xerente - Warã Indigenous High School (CEMIX - WARÃ) and the Sakruiwẽ State Indigenous School. The first one located in the Xerente Indigenous Land and the second in the Indigenous Land Funil. In the development of the research the characteristics of these two schools and the context in which they were found were analyzed, as well as the activities developed by the Akwẽ indigenous teachers who teach in these educational units, in order to perceive the effects of the performance of these schools and Pedagogical actions of Akwẽ teachers in the training of indigenous students. At the end, we followed some methodological steps that included a bibliographic pertinent study to the object of research and to indigenous school education, contact with subjects of the process of school and non-school education in the community and with pedagogical actions in the afore mentioned educational units. This process made us understand that indigenous school education needs to find its way through pedagogical actions in tune with the indigenous social context, in fact to be the indigenous school that the community desires.

Key words: Indigenous school. Indigenous teacher. Pedagogical actions. Akwẽ culture.

\section{INTRODUÇÃO}

Este trabalho de pesquisa foi realizado no Centro de Ensino Médio Indígena Xerente-Warã (CEMIX-WARÃ) e na Escola Estadual Indígena Sakruiwẽ. As duas escolas são do povo indígena Akwẽ-Xerente. A primeira está localizada na Terra Indígena Xerente e a segunda na Terra Indígena Funil. O presente trabalho analisa as características dessas duas escolas e o contexto em que elas se encontram, bem como as atividades desenvolvidas pelos professores indígenas Akwẽ que lecionam nessas unidades de ensino, com o objetivo de perceber os efeitos da atuação dessas escolas e das ações pedagógicas de professores Akwẽ na formação de alunos indígenas.

E, para tanto, seguimos algumas etapas metodológicas. A primeira etapa foi realizar um estudo bibliográfico de autores como Silva (2010), Nolasco (2010), Guimarães (2002), Cotrim (2015), Grupioni (2009), Baniwa (2011) e Barroso (2009), que discutem a educação indígena e a educação escolar indígena, não deixando 
escapar a legislação educacional que normatiza a educação brasileira, com foco na educação dos povos indígenas. É interessante ressaltar que os trabalhos utilizados, que abordam o contexto indígena, serviram como base para fundamentação desta pesquisa e estão intrinsecamente ligados aos povos indígenas e à própria comunidade indígena Akwẽ. As experiências desses pesquisadores fortalecem a discussão sobre o assunto, uma vez que vivenciaram os processos de educação nas comunidades.

A segunda etapa concentrou-se no contato com alunos, professores, pais e comunidades, seguindo os exemplos dos autores acima citados. Essa fase favoreceu uma experiência extremamente enriquecedora quanto à percepção da educação escolar indígena do povo Akwẽ e foi útil por promover diálogos com sujeitos da educação escolar indígena, sendo fundamental para compreensão da realidade peculiar que se manifesta nas escolas indígenas Akwẽ.

Além disso, esses diálogos nos favoreceram para o contato direto com os processos de educação, bem como com os anciãos da comunidade. Ancião é um sábio da comunidade, sendo, portanto, respeitado por todos da comunidade, pelo fato de ser o detentor dos conhecimentos tradicionais de seu povo. Essa fase foi, portanto, momento salutar para desenvolver o olhar sobre o contexto social do povo Akwẽ.

Já a terceira fase concentrou-se na nossa observação das execuções de algumas atividades escolares e extraescolares da Escola Estadual Indígena Sakruiwẽ e do Centro de Ensino Médio Indígena Xerente.

E, assim, para adentrar nas discussões sobre as duas escolas e o povo indígena onde realizamos este trabalho, apresentamos então algumas características que consideramos importantes para a compreensão e o entendimento do contexto social indígena Akwẽ.

Quando nos referirmos aos indígenas neste trabalho estaremos usando o termo 'povos indígenas', conforme a adoção da OIT e proposto pelos delegados indígenas da Primeira Conferencia Indigenista realizada em dezembro de 2015 em Brasília, evitando, no entanto, o uso dos termos 'etnia'e 'índios', pois, conforme constatamos, essas nomenclaturas referem-se aos indivíduos marginalizados no continente europeu e foram empregadas na América como referência aos indígenas que vivem em outro contexto social.

Quanto à referência às aldeias procuramos substituir pelo termo 'comunidade' quando necessário. Esses termos precisam 
ser repensados, pois ainda trazem ideologias preconceituosas, inferiorizadoras e de exclusão. Os termos 'povos indígenas' e 'comunidades' são mais amplos, pois reconhecem a cultura, a língua, as tradições e a organização política de cada povo indígena. Temos como exemplo a palavra 'aldeia', que tem sua origem na política de aldeamento das populações indígenas brasileiras no período colonial. Nessa linha, procuramos substituir o termo 'Xerente' pelo 'Akwẽ', que é a autodenominação do povo indígena em que esta pesquisa foi realizada.

Com intuito de favorecer uma maior compreensão deste trabalho, é salutar conhecer o povo indígena Akwẽ. Para tanto apresentamos algumas características fundamentais do povo indígena em destaque. Os Akwẽ estão localizados no estado do Tocantins, a cerca de 70 quilômetros ao norte da Capital do Estado, no município de Tocantínia. Estão distribuídos em duas reservas, uma com denominação de Terra Indígena Xerente e a outra Terra Indígena Funil, somando 183.245.902 hectares (Schroeder, 2010). Atualmente os Akwẽ estão distribuídos em 64 comunidades (aldeias), sendo 57 na Terra Indígena Xerente e 07 na Terra Indígena Funil.

$\mathrm{O}$ povo indígena Akwẽ tem sua estrutura organizacional específica. Na verdade cada povo indígena tem sua forma singular de organização, diferenciando-se dos outros através de diversos modos de expressão. Nessa perspectiva, vamos conhecer o modo de ser do povo indígena Akwẽ na visão de Ivo Schroeder (2010).

Eles se apresentam em duas metades exogâmicas, dividindo a sociedade entre "nós" e "eles". Essas duas metades são divididas da seguinte forma, de um lado, estão os Isake (sdakrã ou wairê) e, de outro, os Dohi (siptato ou dói). Do lado do isake, têm-se os clãs wahirê, krozake e krãiprehi e, do lado Dohi, os clãs kuzâ, kbazi, e krito. Nas pinturas corporais, os primeiros usam como motivo o traço e os últimos, o círculo. Além da exogamia, essa estrutura comanda a vida ritual, na qual clãs confrontantes que se tratam por dasiwaze devem trabalhar juntos, tal como na nomeação feminina ou ainda realizar o enterro e o ritual do kupre, um lado para outro. $\mathrm{Na}$ política novamente comparecem as metades e os clãs, obrigando ao respeito e ao apaziguamento nos conflitos de um lado pelo outro (Schroeder, 2010, pág. 68). 
No contato com a comunidade, um ancião Akwẽ chamado Raimundo Wãikanõse relatou que a população Akwẽ diminuiu, "tinha muito Akwẽ nessa terra, com a chegada dos brancos, chegaram também muitas doenças e guerras que quase acabaram com nosso povo. É assim que os nossos velhos nos contaram". Constatamos que essa afirmação é verídica, pois a partir dos aldeamentos têm-se os dados populacionais do povo Akwẽ em declínio. A população Akwẽ era de 2.200 em 1851 (Tággia, 1956), 1.360 em 1924 (Viana, 1927) e 1.000 (FUNAI, 1987 apud RICARDO e RICARDO, 2006). No entanto, a partir da década de 1990 a população começou a aumentar significativamente para 1.675 (FUNAI, 1996 apud GUIMARÃES, 2002), 1366 (IBGE, 2000) e 3.017 (FUNASA, 2010 apud RICARDO e RICARDO, 2011).

Sob os olhos do governo brasileiro a população indígena passou por situações em que não se respeitou as diferenças existentes. E para mostrar ações voltadas às populações indígenas criou-se o Serviço de Proteção aos Índios (SPI) em 20 de junho de 1910, pelo Decreto $\mathrm{n}^{\circ}$ 8.072. O SPI tinha como objetivo prestar assistência a todos os índios do território nacional (Oliveira, 1947). Com a extinção do SPI, por meio da Lei $\mathrm{n}^{\mathrm{o}} 5.371$ de 5 de dezembro de 1967 foi criada a Fundação Nacional do índio (FUNAI), tendo como sua missão institucional proteger e promover os direitos dos povos indígenas no Brasil.

Somente a partir de 1988 foi que a Constituição Federal brasileira tornou claro o reconhecimento aos direitos dos povos indígenas. Em seu Artigo 231 assevera que "são reconhecidos aos índios sua organização social, costumes, língua, crenças e tradições, e os direitos originários sobre as terras que tradicionalmente ocupam, competindo à União demarcá-las, proteger, e fazer respeitar todos os seus bens".

Sabemos que é necessário um estudo mais detalhado para explicar a decadência do número de populações indígenas no Brasil, em especial do povo indígena Akwẽ. Observamos que no início do aldeamento a população Akwẽ ainda apresentava um número grande de indígenas, mas que aos poucos esse número foi reduzindo drasticamente. Talvez voltando a crescer a partir das demarcações de suas Terras Indígenas, que afastaram a presença de não indígenas.

Outra possibilidade que temos é inserção explícita de um capítulo sobre os direitos indígenas na Constituição Federal de 1988. Esses dois momentos impossibilitaram os não indígenas de 
realizarem atividades de caças e pescas, bem como outras atividades nos territórios indígenas. Observamos que nas fronteiras existem placas que proíbem a presença e o exercício de qualquer atividade por pessoas estranhas nas terras demarcadas.

Por isso tudo, 1988 é um marco histórico para todos os povos indígenas brasileiros, pois o assunto que estamos trabalhando começa a se formar nesse período entre o povo Akwẽ. A educação escolar é uma novidade para esse povo, pois a educação interna tradicional, em sua maior parte ocorria no contato com os pais, comunidades e o Warã, que a casa dos homens, um elemento fundamental para os Akwẽ.

A educação escolar pode ser destacada como um projeto de duas faces. Primeiro por se tratar de um projeto de interesses das políticas não indígenas, com os objetivos de descaracterizar os povos indígenas, sendo, portanto, um elemento de dominação. E por possibilitar aos povos indígenas ferramentas de lutas por seus direitos e construção de argumentos em face do governo para o cumprimento dos direitos humanos, direitos fundamentais e indígenas, de acordo com a Constituição Federal, Estatuto do Índio e outras normas internacionais. E sobre essa compreensão estaremos discutindo ao longo desse trabalho realizado na comunidade e escola.

Adiantando, podemos dizer que a discussão voltada aos povos indígenas no âmbito da educação, aos poucos, vem conquistando espaço e sendo destacada pelos estudiosos dessa área, pois pensar a educação no contexto dos povos indígenas exige complexos estudos e análises. Percebe-se que a participação dos povos indígenas, há muito tempo ficou invisível ou mesmo não eram consultados para discutir a sua própria educação. Dessa forma não ocorriam diálogos com os povos indígenas, que passaram a contar com a educação escolar. Mesmo sem sua participação, o governo brasileiro implantou os projetos de educação nas comunidades indígenas.

Destacamos, no entanto, que para o povo indígena Akwẽ a educação escolar revela-se como formas de ensino não indígena. Sabe-se que cada povo indígena do Brasil ou de qualquer parte do mundo possui formas próprias de ensino que vem desde os tempos imemoriais. Esses processos pedagógicos a nosso ver contribuem para desenvolvimento de ações do cotidiano indígena, frente aos diversos aparecimentos de produtos e ideologias que estão em desacordo com os conhecimentos indígenas, mas com a inserção da educação escolar nas comunidades indígenas, possibilitou-se acesso aos conhecimentos não indígenas. 
Neste estudo vamos identificar de que forma este se relaciona com os conhecimentos indígenas, e como são trabalhados nas escolas e nas comunidades. Compreendemos que a educação escolar, por sua vez, foi implantada entre os povos indígenas com objetivos contrários aos propósitos de educação indígena, pois essa forma de educação se pautava nos princípios integracionistas, tendo como fim a homogeneização das populações indígenas, sem se pensar nas diferenças existentes. Fato que se confirma na presença de professores não indígenas que lecionavam nas escolas criadas nas comunidades indígenas. Esses professores normalmente eram servidores da FUNAI ou de igrejas.

A educação de que estamos tratando aqui é aquela que vem através de escola, em que o ensino se dá dentro de sala com quatro paredes ou raras vezes em ocas ou casas de palhas que as comunidades ofereceram para o seu funcionamento. É interessante pensar que essa escola veio para destruir todos os conhecimentos construídos ao longo da existência dos povos indígenas. Nessa pesquisa, procuramos pensar essas primeiras escolas de modelo europeu e a educação escolar indígena que vem com um objetivo inovador, propondo um diálogo aberto entre os conhecimentos, as ciências indígenas e não indígenas.

Para sistematizar melhor este trabalho, dividimos em quatro seções com intuito de melhor compreendermos os resultados da pesquisa. Nesse contexto, na primeira seção trouxemos uma discussão sobre a educação escolar indígena com base na legislação brasileira. Na segunda seção nos propomos a trazer considerações pertinentes às duas unidades de ensino que são objeto do nosso estudo, a Escola Estadual Indígena Sakruiwẽ e o Centro de Ensino Médio Indígena Xerente. Nessa seção vamos apontar as principais características dessas duas escolas indígenas do povo Akwẽ. A quarta seção vem discutir de fato as práticas pedagógicas dos professores Akwẽ, seguida pela quinta seção, que trata das implicações das ações pedagógicas dos professores Akwẽ na formação dos alunos indígenas.

\section{Política de educação escolar indígena segundo a legislação educacional brasileira}

Para contextualizar a educação indígena é necessário pensar sobre a política cultural dos povos indígenas, pois esse aspecto é 
pilar para as lutas pela educação escolar indígena que se apresentam atualmente no Brasil. Ao longo desse trabalho vamos, de alguma forma, nos referir sobre a educação não escolar, ou seja, a educação existente nas comunidades indígenas que respeitam suas organizações culturais.

Conforme constatamos, a oferta de educação para os povos indígenas, amparada por lei, veio muitos anos depois de contatos iniciados em 1500, pois as cartas magnas de 1824, 1891, 1934, 1937, 1946 e 1967 não mencionam sobre a educação para os povos indígenas, nem sequer fazem alguma referência de qualquer natureza aos primeiros habitantes do Brasil. A partir desses documentos oficiais verificamos que os povos indígenas eram tidos como povos invisíveis ou mesmo inexistentes no território brasileiro. Desde muito antes da introdução da escola, os povos indígenas vêm elaborando, ao longo de sua história, complexos sistemas de pensamento e modos próprios de produzir, armazenar, expressar, transmitir, avaliar e reelaborar seus conhecimentos e suas concepções sobre o mundo, o homem e o sobrenatural.

E para amenizar essa postura histórica da política brasileira de ignorar os povos indígenas, veio então a Constituição Federal de 1988, expressando um novo entendimento sobre a situação das populações indígenas. Nascem dessa forma as garantias dos direitos dos povos indígenas, quanto ao reconhecimento da organização social, costumes, línguas, crenças, tradições, bem como os direitos sobre as terras, não se excluindo os direitos sociais garantidos pela mesma Carta Magna. Conforme Artigo $6^{\circ}$ da Constituição Federal "são direitos sociais a educação, a saúde, a alimentação, o trabalho, a moradia, o transporte, o lazer, a segurança, a previdência social, a proteção à maternidade e à infância, a assistência aos desamparados, na forma desta Constituição".

Dentro desses direitos conferidos aos indígenas vamos nos ater ao da educação, que é objeto do nosso estudo. A educação oferecida aos povos indígenas ao longo do processo de colonização não reconhecia os aspectos inerentes às populações indígenas. No entanto, a lei maior trouxe um novo entendimento à educação escolar indígena. Primeiro ao afirmar que a educação é direito de todos e que é dever do estado e da família a sua promoção, trazendo para tanto a sociedade, visando o desenvolvimento da pessoa para o exercício da cidadania e qualificação para o trabalho.

Segundo por normatizar em seu Artigo 210, parágrafo segundo, que "o ensino fundamental regular será ministrado em 
língua portuguesa, assegurada às comunidades indígenas também a utilização de suas línguas maternas e processos próprios de aprendizagem". Além disso, de acordo com o Artigo 215, parágrafo primeiro "o Estado protegerá as manifestações das culturas populares, indígenas e afro-brasileiras, e das de outros grupos participantes do processo civilizatório nacional".

Amparada pelos preceitos da Constituição Federal de 1988 a Lei de Diretrizes e Bases da Educação Nacional (LDBEN), Lei $n^{\circ}$ 9.394 de 20 de dezembro de 1996, repetiu os dispositivos da Carta Magna e editou um entendimento mais específico sobre a educação escolar indígena, estabelecendo que essa deve ser diferenciada, bilíngue e intercultural. Conforme o Artigo 78 da LDB,

\begin{abstract}
O Sistema de Ensino da União, com a colaboração das agências federais de fomento à cultura e de assistência aos índios, desenvolverá programas integrados de ensino e pesquisas, para oferta de educação escolar bilíngüe e intercultural aos povos indígenas, com os seguintes objetivos: I - proporcionar aos índios, suas comunidades e povos, a recuperação de suas memórias históricas; a reafirmação de suas identidades étnicas; a valorização de suas línguas e ciências; II - garantir aos índios, suas comunidades e povos, o acesso às informações, conhecimentos técnicos e científicos da sociedade nacional e demais sociedades indígenas e não-índias (BRASIL, 1996).
\end{abstract}

O Artigo 79, por sua vez, em seus incisos I, II, III e IV, estabelece que os programas integrados de ensino e pesquisa, desenvolvidos pelo governo federal, incluídos nos Planos Nacionais de Educação, terão os seguintes objetivos:

I - fortalecer as práticas sócio-culturais e a língua materna de cada comunidade indígena; II - manter programas de formação de pessoal especializado, destinado à educação escolar nas comunidades indígenas; III - desenvolver currículos e programas específicos, neles incluindo os conteúdos culturais correspondentes às respectivas comunidades; IV elaborar e publicar sistematicamente material didático específico e diferenciado (BRASIL, 1996). 
O Referencial Curricular Nacional para as Escolas Indígena traz como fundamentos para a educação escolar indígena os princípios de multietnicidade, pluralidade e diversidade. Apresenta também as características das escolas indígenas como sendo comunitárias, interculturais, bilíngues/multilíngues, específicas e diferenciadas. A Resolução $\mathrm{n}^{\mathrm{o}}$ 5, de 22 de junho de 2012, que define as Diretrizes Curriculares Nacionais para a Educação Escolar Indígena na Educação Básica, tem por objetivos,

I - orientar as escolas indígenas de educação básica e os sistemas de ensino da União, dos Estados, do Distrito Federal e dos Municípios na elaboração, desenvolvimento e avaliação de seus projetos educativos; II - orientar os processos de construção de instrumentos normativos dos sistemas de ensino visando tornar a Educação Escolar Indígena projeto orgânico, articulado e sequência do de Educação Básica entre suas diferentes etapas e modalidades, sendo garantidas as especificidades dos processos educativos indígenas; III - assegurar que os princípios da especificidade, do bilingüismo e multilinguismo, da organização comunitária e da interculturalidade fundamentem os projetos educativos das comunidades indígenas, valorizando suas línguas e conhecimentos tradicionais; IV - assegurar que o modelo de organização e gestão das escolas indígenas leve em consideração as práticas socioculturais e econômicas das respectivas comunidades, bem como suas formas de produção de conhecimento, processos próprios de ensino e de aprendizagem e projetos societários; V - fortalecer o regime de colaboração entre os sistemas de ensino da União, dos Estados, do Distrito Federal e dos Municípios, fornecendo diretrizes para a organização da Educação Escolar Indígena na Educação Básica, no âmbito dos territórios etnoeducacionais; VI - normatizar dispositivos constantes na Convenção 169, da Organização Internacional do Trabalho, ratificada no Brasil, por meio do Decreto Legislativo $\mathrm{n}^{\circ}$ 143/2003, no que se refere à educação e meios de comunicação, bem como os mecanismos de consulta livre, prévia e informada; VII - orientar os sistemas de ensino da União, dos Estados, do Distrito Federal e dos 
Municípios a incluir, tanto nos processos de formação de professores indígenas, quanto no funcionamento regular da Educação Escolar Indígena, a colaboração e atuação de especialistas em saberes tradicionais, como os tocadores de instrumentos musicais, contadores de narrativas míticas, pajés e xamãs, rezadores, raizeiros, parteiras, organizadores de rituais, conselheiros e outras funções próprias e necessárias ao bem viver dos povos indígenas; VII - zelar para que o direito à educação escolar diferenciada seja garantido às comunidades indígenas com qualidade social e pertinência pedagógica, cultural, linguística, ambiental e territorial, respeitando as lógicas, saberes e perspectivas dos próprios povos indígenas.

Nessa perspectiva podemos dizer que avançou e tanto a discussão quanto ao conceito de povos indígenas. Dentro dessa discussão sobre a educação escolar indígena, conhecimentos e culturas indígenas, a legislação tem se colocado a favor dos povos indígenas, tanto que a Lei $\mathrm{n}^{\mathrm{o}} 11.645 / 2008$ obriga a inclusão da temática "história e cultura Afro-Brasileira e Indígena" nos currículos de toda rede de ensino no Brasil. Outro ponto interessante que nos faz compreender o avanço da legislação sobre a promoção de educação escolar aos povos indígenas é a promulgação da convenção $n^{\circ} 169$ da Organização Internacional do Trabalho sobre os direitos dos povos indígenas e tribais, entre eles o da educação escolar indígena em todos os níveis e nas mesmas condições que o restante da comunidade nacional.

E, assim, esse novo cenário tem possibilitado a discussão e criação de programas para educação escolar indígena que atendam aos projetos e interesses dos povos indígenas e respeitem a autodeterminação e as culturas dessas sociedades.

\section{Considerações sobre o Centro de Ensino Médio indígena Xerente - Warã e a Escola Estadual Indígena Sakruiwẽ}

Entre o povo indígena Akwẽ existem hoje, segundo os dados da Secretaria Estadual de Educação, 31 escolas. Para trazer algumas considerações sobre escolas indígenas Akwẽ, realizamos trabalho de pesquisa em apenas duas escolas distintas, o Centro de Ensino Médio Indígena Xerente - Warã e Escola Estadual Indígena Sakruiwẽ. São 
distintas em vários aspectos que vão desde sua localização, até suas ações para formação dos alunos Akwẽ. A política de organização também se encontra de forma diferente no contexto dessas duas unidades de ensino. E, assim, para essa compreensão realizamos então considerações de cada uma das instituições.

O Centro de Ensino Médio Indígena Xerente - Warã localizase na Terra Indígena Xerente, e, juntando as duas Terras Indígenas do povo Akwẽ, percebe-se que ela está no centro do território Akwẽ. Antes da implantação dessa escola havia a aldeia Centro Nrõwdêzakrdi, há cerca de 200 metros do local, mas quando foi pensada sua implantação não havia nenhuma comunidade no local e somente depois surgiu nas proximidades à aldeia Coqueiro.

Essa unidade de ensino é considerada pelo povo Akwẽ como a escola de todos, por isso foi criada longe de comunidades e no centro do território Akwẽ, para que nenhum Akwẽ pudesse dizer "sua escola" ou "escola da minha comunidade", mas sim "escola do povo indígena Akwẽ". As lideranças que participaram dessa luta para a construção de um Centro de Ensino Médio, além de pensarem uma escola para o povo, pensaram também na preservação dos aspectos culturais do seu povo.

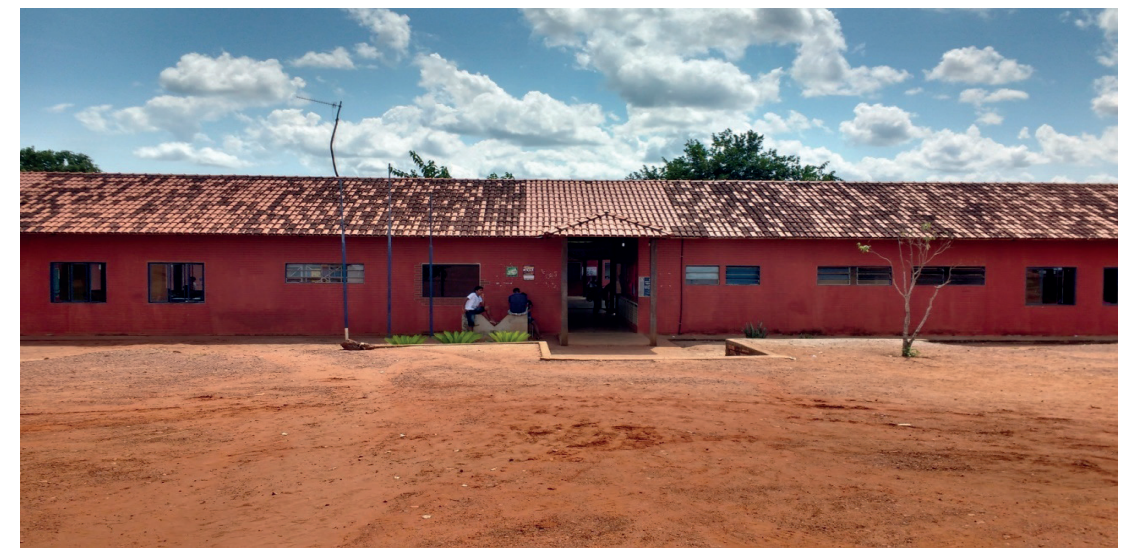

Figura 01: Centro de Ensino Médio Indígena Xerente - Warã. Foto: Rogério S. Xerente/2016.

A Escola Estadual Indígena Sakruiwẽ, por sua vez, localizase na Terra Indígena Funil, na aldeia Funil Sakrêpra. As lutas para criação desta escola foram do povo dessa única comunidade que existia na época, pois queriam oferecer educação inicial para 
crianças que mais tarde iriam estudar nas cidades de Tocantínia ou Miracema do Tocantins. No início da expansão da educação escolar entre o povo Akwẽ, era oferecido ensino somente nas séries iniciais na própria comunidade.

Nesse sentido, aqueles que quisessem prosseguir nos seus estudos tinham que sair de suas comunidades e ir para a cidade enfrentar desafios não conhecidos. Na verdade, os estudantes indígenas queriam prosseguir os estudos, mas vários fatores dificultavam o acesso dos Akwẽ à educação. Até o ano de 2005, essa ainda era a realidade Akwẽ quanto ao acesso à Educação Fundamental dos anos finais e Ensino Médio. Conforme pode se constatar, essa era uma demanda antiga dos povos indígenas

O ensino fundamental completo já é uma demanda de várias aldeias, como meio de evitar que alunos indígenas, ao terminarem a $4^{\mathrm{a}}$ série, sejam obrigados a se transferirem para escolas mais próximas, na cidade, onde não são consideradas suas necessidades educacionais específicas (RCNE/Indígena, pág. 14, 1998).

Constata-se hoje que a implantação do Centro de Ensino Médio Indígena Xerente - Warã fez surgir um novo diálogo na educação escolar indígena com os ensinos dos anos iniciais e finais do fundamental e médio. Praticamente todas as crianças que estão no início dos seus estudos quando perguntadas onde querem estudar depois de concluir o $5^{\circ}$ ano dão a resposta sempre que será no Cemix - Warã.

Foi durante a pesquisa que refletimos sobre a valorização das escolas indígenas pelo povo Akwẽ, pois isso mostra o quanto a luta das lideranças e das comunidades Akwẽ é em benefício de todos. Eles, no entanto, reconheceram que era necessário o avanço da educação escolar Akwẽ, promovendo ambientes e ações de ensino voltadas para as comunidades Akwẽ. Os profissionais de educação antes eram quase todos não indígenas. Hoje o cenário é diferente e aponta que em breve todos os profissionais da educação escolar indígena serão indígenas. A cada ano os indígenas vêm entrando nas universidades, com intuito de expandir seus conhecimentos e com isso possibilitar o seu bem estar e da comunidade.

Apesar de pouco tempo de educação escolar Akwẽ ter seguido essa linha de pensamento, os resultados quanto aos números de 
indígenas que conseguem concluir o ensino médio superam os de todos os períodos anteriores. Isso graças às lutas incansáveis das lideranças Akwẽ que passaram por diversas situações que dificultaram os resultados positivos quanto ao atendimento dos seus anseios. Dessas lideranças que muitas vezes deixaram suas famílias para lutar em prol de todo o povo Akwẽ e não se encontram mais entre nós.

As conquistas do povo Akwẽ demandaram muitas lutas. E com esse olhar vamos conhecer um pouco da história do povo que resultou nas conquistas dessas duas instituições das quais estamos falando. Pois não é de um dia para outro que o Centro de Ensino Médio Indígena Xerente - Warã e Escola Estadual Indígena Sakruiwẽ surgiram. Tem muita coisa envolvida nesse contexto histórico que vamos descrever a partir das narrativas do próprio povo Akwẽ e de documentos que acessamos.

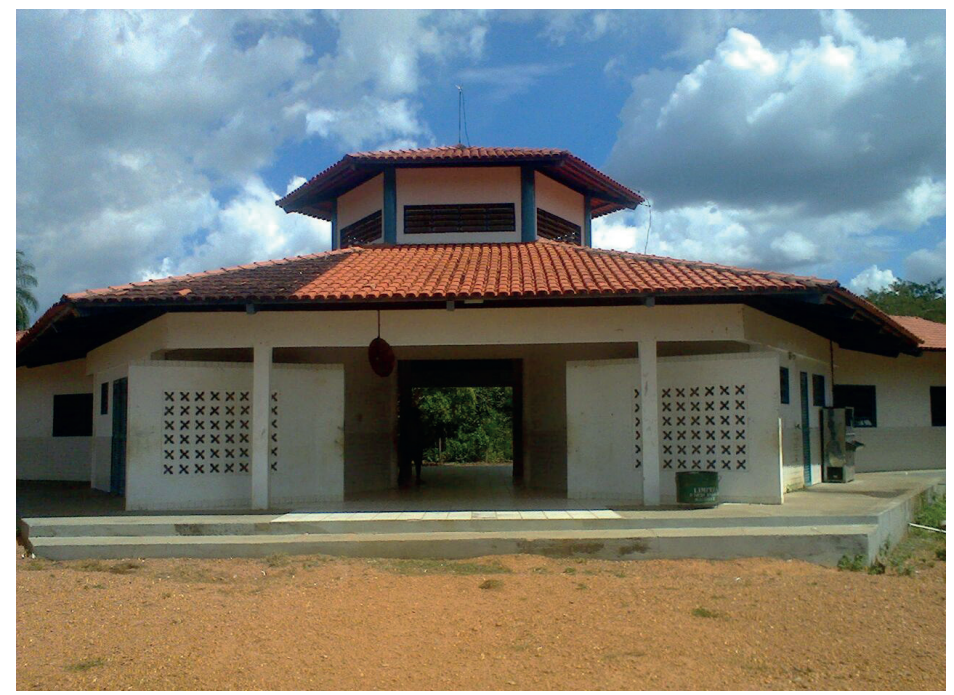

Figura 2: Escola Estadual Indígena Xerente. Foto: Rogério S. Xerente/2016

\section{Práticas Pedagógicas no Centro de Ensino Médio Indígena Xerente - Warã e Escola Estadual Indígena Sakruiwẽ}

Nesta seção vamos apresentar e analisar algumas ações e práticas pedagógicas do Centro de Ensino Médio Indígena Xerente - Warã e da Escola Estadual Indígena Sakruiwẽ e experiências vividas por outros pesquisadores no contexto da educação escolar 
indígena, bem como análises dessas ações nas perspectivas de educação escolar indígena. Nesse contexto, o Centro de Ensino Médio Indígena Xerente - Warã veio para satisfazer o desejo antigo do povo Akwẽ, que é ver os alunos em contato com conhecimentos próprios ao longo de sua formação escolar, pois até então o povo não tinha uma escola de referência para atender seus alunos e dar continuidade no processo de formação iniciada junto às famílias e ensino escolar inicial.

Na realidade, após a conclusão da primeira fase do Ensino Fundamental, os alunos Akwẽ eram obrigados a estudar nas escolas das cidades de Tocantínia, Miracema do Tocantins ou ainda em outras cidades como ficou evidenciado anteriormente, onde enfrentavam diversas dificuldades. Sabe-se que no contexto de educação escolar o contato com o mundo não indígena torna-se inevitável. Pensa-se que com a presença de um Centro de Ensino Médio indígena, apesar desse contato inevitável com o mundo exterior, torna-se possível o trabalho permanente e sustentável das epistemologias indígenas.

Nessa perspectiva, os professores Xerente são agentes que desempenham um novo papel social para sua sociedade (GUIMARÃES, 2002, p. 15). A educação que há pouco tempo ocorria somente de forma tradicional, ou seja, no seio da família e comunidade, passa a ter um novo aliado, a educação escolar através dos professores. Nessa realidade, o professor Akwẽ deve enxergar e conhecer os conhecimentos indígenas e não indígenas, com intuito de promover uma educação reconhecida pela comunidade e pela legislação, pois o Artigo 210, parágrafo $2^{\circ}$, da Constituição Federal, ao abordar o Ensino Fundamental, assegura que "o ensino fundamental regular será ministrado em língua portuguesa, assegurada às comunidades indígenas também a utilização de suas línguas maternas e processos próprios de aprendizagem" (Artigo 210 da CF).

A partir desse pressuposto, no que tange à utilização da língua materna e à pedagogia indígena, seria o meio favorável para a efetivação da educação escolar indígena, frente à imposição de metodologias

proposta de educação que se dizia bilíngüe e tinha como meta servir tanto de propostos religiosos - a evangelização das comunidades indígenas - quanto a estratégia de integração dos povos indígenas à sociedade não-indígena (Silva, 2010, p 12). 
A princípio a educação escolar foi uma imposição aos indígenas com intuito de atender a uma política de exclusão, desigualdade e opressão. Além disso, os meios utilizados no ensino eram estranhos aos conhecimentos indígenas, dificultado muitas vezes o entendimento dos conteúdos ministrados. Conforme assevera Silva, os conteúdos administrados eram os da escola tradicional, com o ensino em português (em geral, com proibição do usa da língua nativa), disciplinar, avaliações baseadas em provas, enfim, uma escola que seguia o modelo vigente no Brasil (Silva, 2010, p. 20).

Para tanto é necessário, segundo Pimentel da Silva (2010),

O reconhecimento da cultura e da língua materna, bem como da realidade intercultural em que se inserem os indígenas, requer que a educação seja capaz de atender a esse desafio entendendo a cultura cotidiana como o ponto de partida para a compreensão de novos conhecimentos e novas metodologias (Silva, 2010, p. 16).

Como adiantado anteriormente, a presente pesquisa tem como propósito trazer algumas ações pedagógicas de professores Akwẽ desenvolvidas durante a realização deste trabalho e as que constam no projeto político pedagógico do Centro de Ensino Médio Indígena Xerente de ensino no ano de 2015. Quer-se também compreender a realidade em que os alunos se encontram na escola, entendendo o cotidiano desses educandos no ambiente de ensino e na comunidade. Nesse aspecto discutiremos sobre as escolas indígenas e a educação escolar Akwẽ, presente no contexto da comunidade.

É interessante ressaltar que o Centro de Ensino Médio Indígena Xerente tem como um dos seus princípios propiciar a valorização e o desenvolvimento de práticas de manifestações culturais do povo indígena Akwẽ. Essa preocupação com a cultura encontra-se em seu Projeto Político Pedagógico (PPP), que é um documento que norteia as ações dessa unidade de ensino. Objetiva-se também, segundo o PPP, que o Centro de Ensino Médio Indígena Xerente - Warã contemple parte das necessidades da comunidade indígena Akwẽ.

A implantação desse centro de educação apresenta um grande passo para o fortalecimento e desenvolvimento da cultura Akwẽ e, mais precisamente, para a sua inclusão no mundo do saber não indígena, se apropriando do seu conhecimento, para entendê- 
lo e percebê-lo nas suas relações com a natureza e com os outros e utilizar-se desses meios para fortalecer-se enquanto indígena. E, para possibilitar essas ações específicas, a grade curricular das escolas indígenas do estado do Tocantins é diferente em parte das escolas estaduais não indígenas, conforme veremos mais a frente.

Para tanto,

Esta proposta abordará as práticas da educação indígena, com os princípios da diferenciação, especificidade, interculturalidade e bilingüismo com qualidade. O Centro de Ensino Médio Indígena Xerente funcionará em regime seriado. A organização curricular implantada respeitará os conhecimentos inerentes da própria cultura, privilegiando o uso da língua materna de cada etnia e objetivando a formação do sujeito pleno, com nível de atendimento voltado para a compreensão do mundo que o cerca, convergindo para a melhoria de qualidade de vida dessas comunidades, defesa de seu território, costumes, tradições e de sua própria inserção na administrativa será moldada em consonância com a forma de organização definida pelas comunidades (PPP, 2015, p. 9).

A partir dessa perspectiva podemos verificar que a escola quer atender à demanda da comunidade, conforme a sua organização em contrapondo aos princípios adotados pela SEDUC-TO. A partir das lutas dos sete povos indígenas no estado do Tocantins, em 2013, a grade curricular comum foi complementada com as disciplinas que pretendem realizar ações específicas voltadas aos conhecimentos de cada povo. Essas disciplinas são Língua Indígena, Educação Indígena, Saúde Indígena, Cosmologia Indígena, Esporte e Lazer, História e Cultura Indígenas, Manifestações Culturais, Arte e Contação de História, de Produção Textual no Ensino Fundamental dos anos iniciais, que possibilita a inserção de mitos e lendas da cultura indígena.

É interessante ressaltar que essas disciplinas foram rejeitadas pela maioria dos pais e também professores indígenas, justificando serem muitas disciplinas que abordam as epistemologias indígenas, falta de material de apoio e diminuição de disciplinas da grade comum, tais como português e matemática. Essa rejeição não afirma 
que trabalhar os conhecimentos indígenas não é importante, segundo afirmam eles.

Para compreender melhor as ações desenvolvidas na unidade de ensino, consultamos o PPP que norteou as atividades da escola no período de 2005 a 2012, no que diz respeito à área do conhecimento, componentes curriculares e competências básicas projetadas, conforme o quadro abaixo.

\begin{tabular}{|c|c|c|}
\hline $\begin{array}{l}\text { Área de } \\
\text { Conhecimento }\end{array}$ & $\begin{array}{l}\text { Componente } \\
\text { Curricular }\end{array}$ & Competências \\
\hline $\begin{array}{l}\text { Linguagens e } \\
\text { Códigos }\end{array}$ & $\begin{array}{l}\text { * Língua } \\
\text { portuguesa } \\
* \text { Língua indígena } \\
* \text { Língua inglesa } \\
\text { * Arte e cultura } \\
* \text { Educação física }\end{array}$ & $\begin{array}{l}\text { * Representação } \\
\text { * Comunicação }\end{array}$ \\
\hline $\begin{array}{l}\text { Ciências da Natureza } \\
\text { e Matemática }\end{array}$ & $\begin{array}{l}\text { * Matemática } \\
* \text { Ciências } \\
\text { * Física } \\
\text { * Química } \\
\text { * Biologia }\end{array}$ & $\begin{array}{l}\text { * Investigação } \\
\text { * Compreensão }\end{array}$ \\
\hline Ciências Humanas & $\begin{array}{l}* \text { História } \\
* \text { Geografia } \\
* \text { Sociologia } \\
* \text { Filosofia }\end{array}$ & $\begin{array}{l}\text { * Contextualização } \\
\text { Sociocultural }\end{array}$ \\
\hline
\end{tabular}

Quadro 1: Área do conhecimento, componentes curriculares e competências básicas projetadas.

O PPP propõe articulação entre as áreas de conhecimentos de acordo com o Referencial Curricular Nacional para as Escolas Indígenas, que sugere alguns propósitos que devem orientar as decisões curriculares:

* Contribuir para que se efetive o projeto de autonomia dos povos indígenas, a partir de seus projetos históricos, 
desenvolvendo novas estratégias de sobrevivência física, linguística e cultural, no contato com a economia do mercado;

* Desenvolver nos alunos e professores a capacidade de discutir os pontos polêmicos da vida em sociedade e oferecer para a comunidade indígena a possibilidade de críticas e conhecimento dos problemas;

* Ser um instrumento para interlocução entre os saberes da comunidade indígena e aquisição de outros conhecimentos interculturais;

* Ser um centro de produção e divulgação dos conhecimentos indígenas para a sociedade envolvente.

Pensar esta articulação pode ser complexo, quando olhamos apenas para o componente curricular, que traz somente a língua indígena e a arte e a cultura, que estão diretamente voltadas para trabalhar conteúdos que abordem as ideologias indígenas, mas também o não indígena em contextos interculturais. Aárea de Ciências Humanas prevê como competências a contextualização sociocultural, em que está nitidamente pensada a abordagem do contexto indígena/ Akwẽ. Quanto a outras áreas, o PPP busca demonstrar essa mesma filosofia, capaz de contribuir com o desenvolvimento da comunidade Akwẽ.

Interessante ressaltar que o ensino de língua portuguesa é pensado como ensino de segunda língua e inglês de terceira língua. A língua indígena fica nesta articulação como ensino de primeira língua, pois é através da língua materna que os alunos entram no processo educacional, sendo sua ferramenta para compreensão de conteúdos desenvolvidos pelos professores na escola e na comunidade. É importante enfatizar que todas as línguas são igualmente importantes e é na perspectiva de valoração da língua e conhecimentos Akwẽ que o ensino de línguas é trabalhado no Centro de Ensino Médio Indígena Xerente- Warã, onde 100\% dos alunos são falantes da língua materna.

A língua Akwẽ e as de outros indígenas eram inferiorizadas no processo de escolarização, uma vez que as línguas indígenas não podiam ser estudadas nas escolas. Independentemente da língua estudada, o uso da língua materna prevalecerá ainda por muitos anos e servirá para o relacionamento interno e a compreensão do mundo externo. Para Pimentel da Silva (2010), 
O importante é lembrar que todas as línguas servirão para veicular conhecimentos tradicionais, científicos, universais, sem diglossia escolar, quando uma língua está reservada aos domínios ditos culturais (história, arte, folclore), e outra, normalmente a língua portuguesa, às ciências, às técnicas e ao comércio (Silva, 2010, p. 17)

Para o desenvolvimento da educação escolar indígena é fundamental a participação de todos nesse processo, não somente os professores, mas toda a comunidade. Os professores indígenas são ferramentas que contribuem com a sua comunidade para transformação da realidade e fortalecimento dos conhecimentos inerentes ao seu povo. Em contato com as comunidades verificamos que os Akwẽ aprovam o ensino que levem em conta os aspectos de sua cultura.

Nesse processo, o professor indígena tem papel fundamental, podendo levar aos alunos os conhecimentos de sua cultura, a fim de contribuir com a aprendizagem, valorizando os conhecimentos construídos ao longo da existência do povo Akwẽ. Para Cotrim (2015),

Os temas contextualizados na realidade indígena, os quais direcionam as práticas pedagógicas Xerente, se estendem para fora do espaço escolar, indo ao encontro da mata, dos riachos, dos animais e do diálogo com mais velhos da comunidade, os wawẽ. Se referem, portanto, à valorização do saber tradicional sobre as plantas e animais medicinais, ao uso e produção de artefatos, à pintura corporal e às formas de respeito entre clãs, à nomeação masculina e feminina, aos mitos de origem (do fogo, da batata-doce, do milho), ao tratamento de parentesco, à corrida de tora de buriti, à roça tradicional, ao casamento cultural, às plantas frutíferas, bem como à sua arquitetura, suas músicas e discursos tradicionais, todos eles pertencentes às mais diversas atividades socioculturais Xerente (Cotrim, 2015, p. 152).

É interessante ressaltar que essa forma de pensar a educação escolar indígena surge com a constituição de 1988, mas principalmente da ação dos próprios indígenas, a partir das lutas para concretização de propostas pedagógicas que atendessem 
aos princípios de educação diferenciada, específica, bilíngue e intercultural. Nota-se, conforme já mencionado, que desde o contato há 516 anos não se pensou nos indígenas, assim como não foi feita consulta para a adoção de princípio pedagógico e político aos povos indígenas. Dessa forma, o estado brasileiro implantou modelo de educação que não correspondia à realidade indígena. No entanto, os indígenas foram expostos a receber ensino escolar durante muito tempo, sem ter uma relação com o modo de ser de seus povos.

Esse modelo de escola européia ainda se faz presente nas comunidades indígenas de todo o Brasil, mas, com amparo legal, a luta pela educação que vem de fato atender à demanda indígena continua e, aos poucos, apresenta em suas atividades pedagógicas o olhar indígena nas escolas. Ao ponto de que hoje a escola torna-se uma grande parceira na luta pela preservação dos aspectos culturais e relação intercultural, para tornar possível o contato com a escrita, para registro da língua materna Akwẽ.

No século XX, na década de 50, temos a chegada de missionários de confissão batista, que implantaram, igualmente, escolas com alfabetização em língua portuguesa, sendo, no entanto, os primeiros a analisarem e documentarem a língua Xerente. Em 1982, propõem a formação de monitores bilíngües dentro do modelo de ensino bilíngue e bicultural definido pelo SIL - Summer Institute of Linguistics (Guimarães, 2002, p. 82).

Além de contribuírem com sistematização da escrita da língua Akwẽ, esses monitores indígenas, começaram desenvolver o ensino da língua materna, bem como a língua portuguesa. Antes dessa ação iniciada pelos missionários batistas, todo o processo educacional era conduzido pelos não indígenas. Somente então nas escolas do povo Akwẽ é que se têm a presença de professores indígenas e consequentemente as ações pedagógicas que utilizam as epistemologias locais, ou seja, o conhecimento do próprio povo indígena.

Para Barroso (2009),

A organização da legislação específica para educação escolar indígena é decorrente da própria atuação de organizações indígenas bem como da articulação entre os vários povos indígenas, numa concepção de acessibilidade do mundo moderno (Barroso, 2009, p. 102). 
Dessa colocação podemos apreender que o movimento indígena nacional teve papel fundamental na consolidação do pensamento indígena, quanto à educação que querem para suas crianças e comunidade. Dela pode se extrair fundamentos da educação específica entendendo que cada povo indígena tem suas características culturais e linguísticas. Desse modo, a educação escolar indígena, além de valorizar os conhecimentos e as práticas pedagógicas específicas, possibilita o acesso ao dito "mundo moderno".

Conforme presenciamos nas duas unidades de ensino, os professores indígenas se preocupam em levar para as salas de aula assuntos referentes à sua cultura, para explicar conteúdos voltados para os conhecimentos indígenas e também não indígenas. Observamos uma aula de matemática em que o professor indígena trabalhou a geometria utilizando pequenos galhos, com os quais formava as figuras. Em outro momento desenhava a casa tradicional do povo Akwẽ, em que se identificavam ângulos, quadrados, retângulos e triângulos.

Esses conhecimentos são inerentes ao modo de como o povo Akwẽ se organiza e vive no seu cotidiano. Nas salas de aula encontramos nas paredes cartazes com desenhos de animais, das aldeias, das pinturas corporais, artesanatos e outras artes. Além disso, as salas de aula da Escola Estadual Indígena Sakruiwẽ são decoradas com as artes do povo Akwẽ, que ficam penduradas em barbantes, tais como: arco e flecha, cofo, esteiras, bordunas, cocares, entre outras.

Com o contato com não indígenas, aos poucos, muito produtos estão entrando na comunidade e isso influencia na língua materna, porque esses produtos eram desconhecidos pelos Akwẽ e por isso não possuem o nome na língua materna, sendo necessárias ações pedagógicas para nomear esses produtos.

Observamos durante a pesquisa a realização de atividades de criação de palavras novas na língua Akwẽ. Por exemplo, celular, bicicleta, carro e escola, e as crianças e os próprios adultos apenas reproduzem da forma que é falada em português. A partir dessas atividades foram criadas as seguintes palavras: târamrmẽ, sumzarkrtikrerê, târawra, rowahtuze, com intuito de nomear os produtos acima citados respectivamente. Como os produtos não indígenas surgem de forma muito rápida, invadem facilmente as comunidades, colocando em risco a vida da língua materna.

Percebemos então que a escola valoriza e faz com que esta não fique distante da realidade dos alunos. Em contatos com escolas 
não indígenas do município de Tocantínia, percebemos as diferenças entre esses tipos de escolas, indígenas e não indígenas. E, para justificar essa diferença, estivemos por quatro momentos em contato com as escolas indígenas e não indígenas.

Em primeiro momento queremos dizer que fomos alunos da escola indígena e tivemos esse contato com a sala aula da aldeia. O segundo momento desse contato, no campo da educação, ainda foi como aluno indígena, mas na escola não indígena. O terceiro e o quarto momentos aconteceram simultaneamente, quando nos tornamos professores de escola indígena e também de escola não indígena.

Essa vivência como alunos que tivemos na escola indígena não nos foi possibilitada na escola não indígena, mas, como professores, nós tivemos a oportunidade de oferecer aos alunos indígenas esse contato permanente com aspectos da cultura Akwẽ nessas duas diferentes escolas. Hoje, atuando somente na escola indígena, podemos visualizar como é a realidade da escola indígena e da não indígena, quanto ao trabalho com as perspectivas indígenas. Verificamos que ainda há alunos que continuam estudando na cidade, sem visualizar, no ambiente escolar, coisas que fazem parte do seu mundo.

Essa escola indígena da qual estamos falando foi também observada por alguns pesquisadores que desenvolveram suas pesquisas entre o povo Akwẽ e destacaram algumas ações pedagógicas de professores indígenas. Na Escola Estadual Indígena Srêmtowẽ da aldeia Porteira, Guimarães (2002, p. 100) observou uma professora que "utilizou os motivos da pintura, traços e círculos para explicar cálculos matemáticos".

Nesse contexto, os professores Akwẽ desenvolvem ações pedagógicas atendendo ao meio social no qual os alunos, a comunidade e os próprios profissionais de educação escolar indígena estão inseridos, mesmo que timidamente. É interessante ressaltar que a escola inserida na comunidade indígena é de modelo europeu e talvez por isso ainda apresente traços marcantes desse tipo de escola, diferente dos modos e espaços de educação propriamente indígena.

A inserção de meios próprios de ações pedagógicas nas escolas indígenas é resultado de lutas dos povos indígenas. Essas ações pedagógicas que vêm contemplando as epistemologias indígenas só foram possíveis com a atuação dos professores indígenas em suas comunidades. É interessante ressaltar que o trabalho do professor 
indígena não se resume apenas ao ensino dos conhecimentos indígenas, mas também dos conhecimentos universais, além de atuar como liderança de sua comunidade e povo.

Quanto às ações pedagógicas de professores Akwẽ, Silva (2010) fez a seguinte observação:

Em várias lousas e desenhos afixados nas paredes de salas de aula pudemos observar a abordagem de conteúdos muito particulares da cultura Xerente: nome de clãs, nomes de animais na língua, referências a festas, mas um tema foi muito recorrente: o estudo da territorialidade Xerente, através de mapas e da identificação de toponímios na língua. É possível que o ensino desses professores esteja atendendo a dois requisitos importantes da educação escolar indígena: à particularidade cultural, sem, porém, que se descuide de aspectos universais, importantes para uma educação que prepare as crianças Xerente para lidarem com a sociedade não indígena (SILVA, 2010, p. 27).

Em outro momento observamos o Centro de Ensino Médio Indígena Xerente - Warã, em que uma professora solicitou para alunos levarem, na aula seguinte, palhas de buriti, para lhes ensinar a confecção de cofos, mas, como essa atividade é típica das mulheres Akwẽ, por isso solicitou para os meninos levarem madeiras como de pati ou pau-brasil e fitas de buriti ou de tucum para confecção de arco e flecha, bordunas e lanças.

Algumas aulas eram ministradas pelos anciãos que os professores levaram para a escola, com o intuito de ensinar aos mais jovens. É salutar enfatizar que os mais velhos não atuam com frequência nesse espaço de educação escolar, talvez pelo fato de que a atuação desses sábios seja no contexto externo da escola. Nesse sentido, o professor indígena tem um papel fundamental na sustentabilidade desse conhecimento milenar.

Como observou Nolasco (2010)

O processo de escolarização trouxe também, além de um método de ensino aprendizagem oposto à educação propriamente Akwẽ, um novo ator social, o professor indígena, que atua no espaço escolar como um tradutor/mediador do conhecimento tradicional e externo, transmitindo-os principalmente por meio da escrita e da leitura (Nolasco, 2010, p.77). 
Ao desenvolver sua pesquisa na Escola Indígena Sinã, da aldeia Rio Sono, Nolasco (2010) observou que

Os mais velhos continuam sendo respeitados por possuírem a sabedoria ancestral e pela maturidade acumulada durante a vida, no entanto, essas duas qualidades, tão prezadas no processo de ensinoaprendizagem daqueles indígenas, não têm sido consideradas na prática escolar e, assim, os mais velhos parecem estar à parte no processo de escolarização (Nolasco, 2010, p.78).

É interessante essa observação pelo fato de que o povo Akwẽ considera os mais velhos bibliotecas vivas. Quanto aos conhecimentos culturais eles são respeitados e até hoje são os detentores da sabedoria tradicional. Esse relacionamento entre os mais velhos e a comunidade como um todo sempre se fez presente no contexto da aldeia para promoção de convivência harmoniosa entre as famílias e os clãs, pois são eles que organizam as festas como o dasĩpê e todas as cerimônias desse evento.

Nesse contexto, a participação dos mais velhos no espaço escolar é extremamente importante para fundamentar as ações pedagógicas do professor indígena. Para contemplar todos os conhecimentos o professor indígena passa a ter a função dos mais velhos na transmissão e construção de conhecimentos do seu povo, bem como das epistemologias não indígenas. Como afirma a pesquisadora "o trabalho do professor índio é o fio condutor desse processo" (Guimarães, 2002, p. 97).

Podemos comparar a educação escolar com a educação tradicional cultural do Warã. O Warã no passado recente era a casa dos rapazes ou espaço de convivências, ensino e aprendizagem do povo Akwẽ. Nesse espaço os anciãos eram os professores que ensinavam aos mais jovens, e por isso o professor indígena não pode perder esse elo com os anciãos no ensino das crianças e jovens.

Com intuito de favorecer as ações pedagógicas nas escolas voltadas para as questões indígenas, nos últimos anos houve um investimento interessante na formação de professores, produção de materiais didáticos pelos próprios professores indígenas criação de disciplinas curriculares específicas. No estado do Tocantins, por exemplo, todas as escolas indígenas passaram a contar, a partir de 2013, com oito disciplinas específicas na grade curricular, conforme 
vimos anteriormente. Os estados promoveram a formação de professores indígenas em nível de magistério e em sequência as universidades federais ofereceram aos professores indígenas a formação superior.

Na formação superior de professores indígenas em licenciatura intercultural ou educação intercultural, a Universidade Federal de Goiás e a Universidade Federal de Mato Grosso se destacaram no cenário nacional. A partir dessa iniciativa de formação de professores indígenas são produzidos alguns materiais usados em salas de aula. Esses materiais produzidos pelos professores indígenas abordam diversas temáticas que levam em conta o contexto indígena.

Conforme Grupioni (2009),

Entre os materiais já editados encontram-se uma variedade de temas, assuntos e abordagens. Há cartilhas para o ensino do português nas "escolas da floresta" e cartilhas de várias línguas indígenas. Há atlas com mapas preparados pelos professores indígenas, que incluem desde registro da origem do universo, na concepção indígena, até o uso da imagem de satélite para precisar áreas de caça e coleta. Há livros que inventariam o acervo de cultura material de um povo indígena, outros trazem receitas, outros que falam dos animais e plantas. Há coletâneas de mitos, de cantos e de histórias. Há dicionários e vocabulários bilíngües. Há livros de histórias, de matemática, de saúde, de geografia e também de poesias. Há livros escritos em diferentes línguas indígenas, outros só em português, e também muitos materiais bilíngues. Alguns trazem apenas textos, mas a maioria está ilustrada com desenhos de variada força estética. A grande maioria são coletâneas de textos, mas há também cartilhas e livros com exercícios na forma de perguntas e atividades para serem realizadas pelos alunos. A maior parte desses livros é apresentada como de autoria indígena coletiva, sendo poucos de autores individuais. Vários deles trazem como organizadores assessores e especialistas universitários (GRUPIONI, 2009, p. 15).

Compreende-se que a produção de materiais didáticos para escolas indígenas tem como base a concepção cultural indígena, 
mas que os materiais produzidos ainda são insuficientes para expor todos os conhecimentos indígenas para as escolas, e talvez nunca serão, pois a oralidade é meio de contato com os ensinamentos na comunidade e mesmo na escola.

Apesar de que a importância e uso da escrita no âmbito de educação escolar são indiscutíveis, ela, "a escrita", divide o espaço com a oralidade que é meio de comunicação muito preservada pelos povos indígenas, inclusive pelos Akwẽ. Nessa linha de pensamento foi possível constatar que as escolas onde desenvolvemos esse trabalho prezam pela manutenção da oralidade. Conforme observou a Guimarães, "os professores operam uma pedagogia que faz a passagem desenho/oralidade/oralidade letrada/escrita característica do processo de aquisição da escritura" (Guimarães, 2002, p. 126).

Para tanto, são desenvolvidas ações pedagógicas em que os alunos praticam atividades culturais. E dentro dessas atividades podemos destacar as que presenciamos com certa frequência: danças, cânticos, corrida de tora, corrida com taquara, cerimônia de casamento, oficinas de pintura corporal e competição com arco e flecha. Nessas atividades, o uso da língua materna pelo professor é fundamental para que os alunos compreendam toda a dinâmica da atividade. Para que isso se tornasse realidade, conforme Guimarães (2002), "a entrada na cena escolar do professor falando a língua Akwẽ dá origem a um traço marcante da sua prática, que é constituir a oralidade em fundamento do processo ensino/aprendizagem" (Guimarães, 2002, p. 115).

No entanto, os desenvolvimentos de ações pedagógicas procuram estar intrinsecamente ligados à questão social do povo Akwẽ. Tende-se a perceber que procura também compreender a realidade da situação que se faz presente, no tocante a escola, aluno e comunidade, bem como o contexto não indígena. Nesse contexto, pode-se pensar quanto à realização de atividades, que professores não indígenas normalmente passam, para que os alunos façam em casa.

$\mathrm{Na}$ escola indígena foi possível perceber que essa prática também se desenvolve na educação escolar indígena. Ao constatar essa prática principalmente no Centro de Ensino Médio Indígena Xerente - Warã nos vieram alguns questionamentos: é possível os alunos fazerem essas atividades? E o contato ou relacionamento com a família e comunidade, como ficam?

Para responder a essas perguntas e outras que com certeza surgem ao pensar o contexto social e ações pedagógicas, é necessário 
se pesquisar mais a fundo. Essas perguntas surgiram quando conversávamos com um aluno que mora na aldeia Brupre e que estuda no Centro de Ensino Médio Indígena Xerente. Ele falou que o ônibus passa às cinco horas da manhã para pegar os alunos dessa comunidade para chegar às sete horas e trinta minutos na escola. Informou ainda que tem aldeia mais longe do que a dele em que o ônibus passa às quatro horas e trinta minutos da manhã.

Em razão do funcionamento do Programa 'Mais Educação' na escola, a unidade liberava os alunos às quinze horas da tarde. Nessa perspectiva, os alunos chegavam à casa às dezesseis horas e trinta minutos, caso o ônibus não apresentasse problema, o que era comum. Nessa lógica, em que momento os alunos indígenas poderiam realizar as atividades de casa? Pois eles já chegavam em casa cansados da viagem e o tempo de relacionamento com a família e a comunidade é reduzido.

Quanto ao mesmo tipo de atividade, na Escola Estadual Indígena Sakruiwẽ, observamos que os alunos tinham tempo de desenvolver, pois a unidade de ensino está dentro da comunidade. Mas outro fator nos chama atenção pelo fato de que a maioria dos pais é analfabeta e não acompanham auxiliando seus filhos na realização de atividades. Podemos pensar que a escola não pode ocupar todo o tempo da criança indígena com atividades que não são vinculadas à sua cultura, pois o cotidiano da criança indígena é diferente do que a escola de modelo europeu e o sistema capitalista pregam.

Nesse aspecto, a escola indígena precisa discutir ações para não limitar o contato com a cultura e a família. A transmissão ou a construção de conhecimento cultural precisam ser preservadas no seio da comunidade e família, mas não é de excluir a importância do professor indígena desse discurso, pois conforme Guimarães (2002) a inserção dos professores Xerente no espaço escolar produziu grande transformação nas práticas discursivas em sala de aula e no impacto dessa atuação sob a sociedade como um todo, ao inaugurar a predominância da língua Xerente na interação professor/aluno (Guimarães, 2002).

\section{As implicações das Ações Pedagógicas de professores Akwẽ na formação de alunos indígenas}

A educação escolar indígena ainda percorre pelo processo que foi instalado com a chegada dos europeus ao solo brasileiro. Esse contato não possibilitou aos indígenas seguir com seus métodos de ensino desenvolvidos por seus antepassados há séculos. Ou melhor, 
os indígenas não foram aceitos da forma que são e como conduzem a sua política interna e de relação externa. Impuseram então aos indígenas a política ocidental dita superior a todas as outras formas de organização. Para tanto, a atuação da igreja através dos padres foi fundamental na introdução dessas ideologias no meio indígena. Essa introdução ocorria principalmente pela prática dos padres nas escolas em que os indígenas foram submetidos a estudar certos conhecimentos alheios aos seus.

Conforme Barroso (2009), a prática da educação nas escolas dos padres tinha como determinação ensinar a importância e o dever da prática do trabalho e converter os índios ao catolicismo, pois, assim, tudo ficaria mais fácil para o governo e a igreja (Barroso, 2009). Por sua vez, dando continuidade ao processo de exclusão e desrespeito ao modo de organização dos povos indígenas, "o SPI assumiu o papel de prestar assistência aos povos indígenas e desenvolveu um processo de escolarização de modelo integracionista fundamentado em ideais positivistas de cunho evolucionista" (Nolasco, 2010, p.37).

Nesse aspecto, todo o conhecimento indígena foi ignorado, com a justificativa de que os povos indígenas deveriam aprender os conhecimentos não indígenas para obterem direitos fundamentais, como se pôde vislumbrar.

Apenas em 1988 a questão indígena passa a ter um espaço dentro da constituição brasileira, de forma mais especificada. Somente na década de 1980 os debates quanto aos povos indígenas ganharam força no cenário nacional e internacional. Apesar da amplitude de debates quanto à questão indígena, as partículas das ideologias eurocêntricas ainda alimentamos não indígenas no contato e no relacionamento com os povos originários. Com a histórica submissão forçada ao mundo estranho, os indígenas ainda lutam para desgrudar-se desse pensamento colonizador.

No entanto, em todo o processo de colonização, os povos indígenas lutaram pela sobrevivência e continuam na briga pela autonomia e respeito às suas particularidades. Para tanto, a comunidade indígena Akwẽ ganhou uma parceira que é a escola. De acordo a Barroso (2009),

As mudanças advindas da introdução das escolas nas aldeias, com sua multiplicidade de referenciais para os professores Akwẽ estão relacionadas à busca de hoje pela autonomia, o processo pelo qual a assimilação não lhes alcança, porque fortalecem 
sua cultura a cada novo entendimento na relação interétnica (Barroso, 2009, p. 72).

Nesse momento em que a escola se faz presente na comunidade, o professor é extremamente importante na elaboração de ações pedagógicas que venham a efetivar a lógica de uma escola indígena Akwẽ. Em nenhum outro período da história da educação escolar indígena essa instituição teve essa oportunidade de trabalhar a temática indígena, mesmo estando no meio e sendo do povo Akwẽ. Destarte o professor indígena deve atender ao anseio antigo do seu povo, de valorizar, respeitar e praticar em sala de aula ou não, a cultura e a língua com seus alunos.

Sobre a ação do professor indígena, Guimarães (2002) tem algumas conclusões. Segundo esse autor,

É possível a revitalização cultural porque o professor se apóia na língua materna; com esse pressuposto, a dinâmica da produção cultural, afetada pelo contexto do contato interétnico, passa a ser refletida na escola por professores e alunos em termos de construir conhecimento. Assim, tradições, costumes antigos, relembrar o passado, a cultura como um todo, a situação atual, passam a ser conteúdo para a construção de um conhecimento sistematizado sobre a realidade sociocultural. Do ponto de vista dos professores, essa discussão fortalece a cultura, trabalha a favor da desaceleração das perdas de práticas sociais, possibilitando, inclusive, a retomada de certas práticas. A relação professor/língua/cultura é enfatizada, sendo a língua o fator principal, o que é explicitamente citado em oposição ao trabalho do professor não-índio que, pela limitação lingüística, não pode ter acesso à cultura (Guimarães, 2002, p. 95).

De acordo com o que já mencionamos, os professores são atores essenciais no ensino das duas epistemologias existentes. Conhecimentos estes que se encontram no contexto indígena e outro no âmbito do não indígena. Desse modo, é através de suas ações que o professor indígena possibilita a avaliação e o entendimento das questões que envolvem os povos indígenas nas relações interculturais. Isso no contexto mais abrangente, conforme menciona Barroso,

A organização da legislação específica para educação 
escolar indígena é decorrente da própria atuação de organizações indígenas bem como da articulação entre os vários povos indígenas, numa concepção de acessibilidade do mundo moderno (Barroso, 2009, p. 102).

Constata-se que a escola auxilia na proposição de atuação dos indígenas na luta pelos seus direitos, na medida em que vão se autoreconhecendo e se autoidentificando como indígenas, pois a escola através da ação do professor pode fazer com que os alunos tenham essa percepção. Nessa perspectiva, o acesso ao mundo moderno, ou seja, ao mundo dos não indígenas, é em grande medida possibilitado pela escola.

Por isso o professor indígena e os princípios adotados pela escola indígena devem possibilitar o conhecimento dos dois mundos já citados. Destarte todos conhecendo o terreno saberão avaliar e escolher o que de fato pode contribuir com a sustentabilidade dos aspectos culturais do povo Akwẽ. Isso porque a globalização está evidente nas aldeias, através da própria escola e as tecnologias que cada dia fazem parte do cotidiano da comunidade.

Guimarães (2002), por sua vez, argumenta que uma das principais funções da escola é fazer aprender a ler e a escrever: "a expectativa de aprender a ler e escrever compartilhada pelas crianças e seus pais é uma das principais funções que se espera da instituição social que é a escola" (Guimarães, 2002, p. 108). Barroso (2009) corrobora com essa afirmação, ao dar importância à prática da escrita pelo povo Akwẽ.

O povo Akwẽ partilha de um processo de dúvidas, aceitaram as escolas como a prática da escrita primeiro do português, depois de sua própria língua, como quem prova de uma comida desconhecida, mas importante para matar a fome desse momento (Barroso, 2009, p. 108).

Quanto à prática de escrita, percebemos que em alguns momentos os professores e pais de alunos exaltam a importância dessa ação, com a justificativa de que o povo Akwẽ deve começar a registrar as suas epistemologias. Confessam que pelo fato dos povos indígenas serem considerados, de acordo com Grupioni (2009), "tradicionalmente ágrafos, por desconhecerem e não fazerem uso 
da escrita, repassando seus conhecimentos por meio da oralidade, ao longo de sucessivas gerações" (Grupioni, 2009, p.11), muitos conhecimentos se perderam ao longo dos anos.

Segundo o entendimento de Nolasco (2010),

Atribuiu-se à escola o papel de, por meio do ensino da escrita e da leitura, revitalizar e valorizar as línguas indígenas, no entanto, alguns estudiosos têm manifestado que para esse fim a escola necessitaria valorizar primeiramente a oralidade e a autonomia dos povos indígenas (Nolasco, 2010, p.73).

Esse autor argumenta ainda que atribuir à escrita a função de revitalizar e valorizar as línguas indígenas parece ser uma opção equivocada, sobretudo, por desconsiderar que essas línguas se reproduzem por meio da oralidade (Nolasco, p.75, 2010). Parecenos que os professores indígenas estão cumprindo com esse dever de pensar a escola e a formação dos alunos. As ações pedagógicas desenvolvidas demonstram esse compromisso, mas é claro que ainda muita coisa precisa ser feita. Percebemos também que o interesse pela formação escolar está vinculado ao desejo de contribuir com sua comunidade. Outro ponto que nos faz pensar a respeito é o fato de que a partir da escola os alunos prezam por preservar, praticar, valorizar todos os aspectos culturais, sobrepondo às demais práticas não indígenas.

É interessante ressaltar que realmente muitos conhecimentos e práticas culturais do povo indígena Akwẽ deixaram de existir, mas esses conhecimentos ainda permanecem vivos nas memórias dos anciãos e através das pesquisas realizadas pelos professores indígenas essas epistemologias chegam até a escola. Temos como exemplo, o Warã, que foi à casa dos rapazes e que não existe mais fisicamente, mas permanece na memória dos mais velhos e a partir da escola os jovens têm contato com esse bem patrimonial do povo Akwẽ. Como se pode imaginar, a escola é o Warã que existiu entre os Akwẽ no passado e, por isso, deve desempenhar o papel de formar as crianças e jovens para vida. Para tanto, o professor indígena tem como dever está inteiramente ligado aos anciãos com intuito de aprender os métodos de ensino e o próprio conhecimento milenar do povo Akwẽ.

Com a formação continuada e o curso de licenciatura em 
Educação Intercultural os professores indígenas intensificaram suas pesquisas com relação à escola e aos conhecimentos culturais do povo Akwẽ. E esse processo também levou à produção de alguns materiais de apoio ao professor Akwẽ.

\section{CONCLUSÃO}

Entendemos que a sociedade é dinâmica, transformando-se culturalmente de acordo com o momento em que ela se encontra. No contexto indígena, essa transformação torna-se mais visível pelo fato de os indígenas terem passado e continuam passando pelo processo de contato intenso com não indígenas. Esse processo não se limita somente ao contato, mas também à imposição de ideologias dos não indígenas no meio dos originários, através de diversas políticas estranhas às suas.

O modelo de escola inserida na comunidade indígena participou decisivamente desse processo de transformação cultural e linguística nas populações indígenas. Muitas histórias, ou melhor, fatos que narram o contato, mostram que as dificuldades se apresentaram ainda no processo de aproximação dos homens brancos com os indígenas. Os aldeamentos desses povos foram uma das possibilidades encontradas, e as ferramentas essenciais nesses ambientes foram as escolas.

Por isso os indígenas e os pesquisadores têm a possibilidade de trazer uma reflexão a respeito do uso da nomenclatura "aldeia" como referência à comunidade. Isso porque o aldeamento, conforme podemos perceber, era uma forma de limitar os indígenas na ocupação de extensos territórios que foram perdidos durante esse processo.

Durante todo o processo voltado para desestabilizar os indígenas do seu meio social natural, a instituição escola ganhou espaço na comunidade por ter se transformado ao longo de sua trajetória e por ter passado a discutir seriamente a sua atuação no contexto indígena. Dessa forma, a presença da escola tornou-se extremamente importante para a comunidade, acreditando que ela vai contribuir na melhoria de vida dos indígenas, pois a escassez de caça e pesca e a atividade de coletas hoje se faz presente na comunidade. Os estudos por sua vez são alternativos para se adentrar no mercado de trabalho na própria comunidade e beneficiar seu povo através desse instrumento.

É evidente que a escola necessita ainda se apresentar como verdadeiro instrumento de transformação na vida desses indígenas, 
sendo necessário desenvolver ações voltadas para preservação da cultura, língua e tradições, de modo que possibilite aos indígenas a compreensão da importância dessa valorização para o próprio povo. Com a globalização as tecnologias tais como, celular, televisão, computador se fazem presente nas comunidades, o que pode provocar nos jovens o interesse maior por estes instrumentos, pois esse contato com os produtos não indígenas vem sendo possibilitado através de sua introdução nas comunidades pela escola e pela própria comunidade.

São várias as ações desenvolvidas pela comunidade que a escola precisa compreender e apoiar. Em alguns momentos nos deparamos com situações específicas na comunidade e na escola, que talvez não se possa encontrar nas escolas da cidade ou de outros povos indígenas. E comum entre o povo Akwẽ a criança acompanhar os pais para roça, pescaria, caçada e visitas aos familiares que moram em outras comunidades. Compreendemos que isso é cultural, pelo fato de que durante a pesquisa aconteceu várias vezes e em famílias diferentes. Dentro dessas ações as crianças estão aprendendo o que talvez dentro da sala de aula não aconteça. Na roça, por exemplo, os pais ensinam como devem cuidar das plantações, saber períodos de plantios, conhecimentos sobre as fases da lua e lugares apropriados para plantios.

No entanto, o acesso ao conhecimento não se dá somente a partir da escrita, a oralidade é tão importante quanto. No meio indígena isso é evidente, pois para eles primeiro vem a oralidade e consequentemente o uso da língua materna, para então acessar a língua externa ou a escrita. Nolasco (2010) corrobora com essa afirmação.

\footnotetext{
[...] é imprescindível repensar o uso da escrita e da leitura como único método de ensino-aprendizagem e criar momentos/espaços, dentro e fora da escola, para que a oralidade, um dos elementos fundamentais no processo de ensino-aprendizagem Akwẽ, seja privilegiada na prática escolar. Esse é um caminho ainda a ser conquistado pelos Akwẽ (Nolasco, 2010, p.75).
}

Podemos concluir que as diversas ações desenvolvidas pelos professores indígenas Akwẽ de fato contribuem com o desenvolvimento dos seus alunos, mas dois pontos interessantes precisam ser pensados para a efetivação dessas práticas. O primeiro é a construção de Projeto Político Pedagógico e o segundo é a sistematização das práticas 
pedagógicas, pois o Centro de Ensino Médio Indígena Xerente Warã existe o Projeto Político Pedagógico, mas a Estadual Indígena Sakruiwẽ não possui esse documento que norteia as atividades pedagógicas de uma escola.

Além disso, as ações pedagógicas precisam ser sistematizadas para fazer parte do processo de escolarização e evidentemente caracterizar a unidade de ensino como sendo uma escolar indígena. As ações desenvolvidas não podem ficar sem ser documentadas, pois isso poderia contribuir ainda mais para o reconhecimento das práticas pedagógicas pela sociedade e a pela Secretaria de Educação do Estado do Tocantins. Esse pode ser um caminho para a escola indígena conseguir sua autonomia para gestar a educação escolar indígena e excluir todas as formas de opressão sofridas pelos indígenas ao longo da história do Brasil. Conforme Baniwa (2011), "é evidente que se a escola for anti-colonialista, indígena, autônoma, diferenciada e intercultural, será sempre melhor" (Baniwa, 2011, p. 35).

A educação escolar indígena necessita, no entanto, encontrar o caminho através de ações pedagógicas em sintonia com o contexto social indígena, para de fato ser a escola indígena que a comunidade deseja. Entretanto, apesar de toda essa legislação, ainda são poucas as escolas em áreas indígenas que podem ser consideradas específicas, diferenciadas e interculturais e voltadas para os cotidianos indígenas no Brasil (Nolasco, 2010, p. 42).

\section{REFERÊNCIAS}

BANIWA, Gersem José dos Santos Luciano. Educação para manejo e domesticação do mundo: entre a escola ideal e a escola real: Os dilemas da educação escolar indígena no Alto Rio Negro (tese de doutorado). UNB. Brasília DF, 2011.

BARROSO, Lídia Soraya Liberato. Azzê Sikutõri Para não Esquecer: a oralidade e o conhecimento da escrita. (Tese de doutorado). Fortaleza, 2009.

BRASIL. Lei $n^{\circ} 11.645$, de 10 de março de 2008. Disponível em: http:// www.planalto.gov.br/ccivil_03/_ato2007-2010/2008/lei/111645.htm. Acesso em: 23/04/2016.

. Lei $n^{\circ} 9.394$, de 20 de dezembro de 1996. Disponivel em: http:// www.planalto.gov.br/ccivil_03/leis/19394.htm23/04/2016. Acesso em: 23/04/2016. 
. Constituição da República Federativa do Brasil de 1988. Disponível em: http:/www.planalto.gov.br/ccivil_03/Constituicao/ConstituicaoCompilado.htm. Acesso em: 08/05/2016.

. Constituição da República Federativa do Brasil de 1967. Disponível em: http://www.planalto.gov.br/ccivil_03/Constituicao/Constituicao67. htm. Acesso em: 23/04/2016.

. Constituição dos Estados Unidos do Brasil (de 18 de setembro de 1946). Disponível em: http://www.planalto.gov.br/ccivil_03/Constituicao/ Constituicao46.htm. Acesso em: 22/04/2016.

. Constituição dos Estados Unidos do Brasil (de 10 de novembro de 1937). Disponivel em: http://www.planalto.gov.br/ccivil_03/Constituicao/ Constituicao37.htm. Acesso em: 22/04/2016.

. Constituição da República dos Estados Unidos do Brasil (de 16 de julho de 1934). Disponível em: http:/www.planalto.gov.br/ccivil_03/ Constituicao/Constituicao34.htm. Acesso em: 22/04/2016.

. Constituição da República dos Estados Unidos do Brasil (de 24 defevereiro de 1891). Disponível em: http://www.planalto.gov.br/ccivil_03/ Constituicao/Constituicao91.htm 22/04/2016. Acesso em: 22/04/2016.

BRASIL. Constituição Política do Império do Brasil, elaborada por um Conselho de Estado e outorgada pelo Imperador D. Pedro I, em 25.03.1824. Disponível em: http://www.planalto.gov.br/ccivil_03/Constituicao/Constituicao24.htm. Acesso em: 22/04/2016.

CENTRO DE ENSINO MÉDIO INDÍGENA XERENTE - WARÃ. Projeto Político Pedagógico (PPP) do Centro de Ensino Médio Indígena Xerente - Warã. Tocantínia: CEMIX-WARÃ, 2015.

COTRIM, Rodrigo Guimarães Prudente Marquez. Comitê Xerente. PIMENTEL DA SILVA, Maria do Socorro; BORGES, Mônica Veloso (Organizadoras). Práticas Pedagógicas de Docentes Indígenas. Goiânia: Gráfica/UFG, 2015.

FUNDAÇÃO NACIONAL DO ÍNDIO. Serviço de Proteção aos Índios - SPI. Disponível em: http://www.funai.gov.br/index.php/servico-de-protecao-aos-indios-spi. Acesso em: 30/12/2015.

GRUPIONI, Luís Donizeti Benzi. Tempos de escritas. $2^{\mathrm{a}}$ ed. Rio de Janeiro: Museu do índio, 2009.

GUIMARÃES, Susana Martelletti Grillo. A aquisição da escrita e diversidade cultural: A prática dos professores Xerente. Brasília: DEDOC FUNAI, 2002.

INSTITUTO BRASILEIRO DE GEOGRAFIA E ESTATÍSTICA. Censo demográfico 2000. Rio de Janeiro-RJ: IBGE, 2000. 
MINISTÉRIO DA EDUCAÇÃO. Diretrizes Curriculares Nacionais para a Educação Escolar Indígena. In Diretrizes Curriculares Nacionais para a Educação Básica: diversidade e inclusão/Organizado por Clélia Brandão Alvarenga Craveiro e Simone Medeiros. - Brasília: Conselho Nacional de Educação: Ministério da Educação, Secretaria de Educação Continuada, Alfabetização, Diversidade e Inclusão, 2013.

. Resolução CEB $N^{\circ}$ 3, de 10 de novembro de 1999. Disponível:http://www.funai.gov.br/arquivos/conteudo/cogedi/pdf/LEGISLACAO_INDIGENISTA/Educacao/RESOLUCAO-CEB-N-3-DE-10-11-1999.pdf. Acesso em: 23/04/2016.

. Referencial curricular nacional para as escolas indígenas. Brasília-DF: MEC/SEF/DPEF Coordenação Geral de Apoio às Escolas Indígenas, 1998.

NOLASCO, Genilson Rosa Severino. Rowahtuze sinã: Um estudo sobre a "pedagogia" Akwê e Educação Escolar Indígena no Tocantins. Dissertação (Mestrado Antropologia Social e Cultural) "Programa de Mestrado em Antropologia Social e Cultural: Conflitualidade e Mediação Cultural no Mundo Contemporâneo", do Departamento de Ciências da Vida da Faculdade de Ciências e Tecnologia da Universidade de Coimbra.

ORGANIZAÇÃO INTERNACIONAL DO TRABALHO. Convenção $n^{\circ}$ 169 sobre povos indígenas e tribais e Resolução referente à ação da OIT/ Organização Internacional do Trabalho. Brasília: OIT, 2011.

PIMENTEL DA SILVA, Maria do Socorro. Reflexão político-pedagógica sobre educação bilíngüe intercultural. ROCHA, Leandro Mendes, PIMENTEL DA SILVA, Maria do Socorro, BORGES, Mônica Veloso (Orgs). Cidadania, interculturalidade e formação de docentes indígenas. Goiânia: Editora da PUC Goiás, 2010.

RICARDO, Beto; RICARDO, Fany (E. E.). Povos indígenas no Brasil: 2006-2010. São Paulo: Instituto Socioambiental, 2011. cioambiental, 2006.

SILVA, Joana Aparecida Fernandes. Educação indígena na área Xerente: apropriação e reforço cultural. ROCHA, Leandro Mendes, PIMENTEL DA SILVA, Maria do Socorro. BORGES, Mônica Veloso (Orgs). Cidadania, interculturalidade e formação de docentes indígenas. Goiânia: Editora da PUC Goiás, 2010.

SILVA, Luiz Fernando Villares e. (Org.). Coletânea da legislação indigenista brasileira. - Brasília: CGDTI/FUNAI, 2008. 
TAGGIA, Rafael (Frei). Mappa dos índios Cherentes e Chavantes na nova povoação de Teresa Cristina do rio Tocantins, aldeados em 24/06/1851. In Rev. do Instituto Histórico e Geográfico do Brasil, Rio de Janeiro: IHGB, Tomo 19, p. 119-22, 1856.

VIANNA, Urbino. Algumas notas sobre os Xerente. Akuen ou Xerente. Ligeiras notas para a grammatica Akuen. In Rev. do Instituto Histórico e Geográfico do Brasil, Rio de Janeiro: IHGB, Tomo 101, v. 155, p. 6-96, 1927. 